\title{
SERVICE OF PROCESS ON FOREIGN CORPORATIONS IN THE STATE COURTS
}

$T_{\text {here has been a }}$ tendency in recent years to relax the requirements which must be met before a state court may assert jurisdiction over a foreign corporation. ${ }^{1}$ The foreruner in this development has been a Maryland statute ${ }^{2}$ which abandons any requirement of extended activity within the state as a condition of jurisdiction and exposes foreign corporations to service of process on any cause of action arising out of a contract executed or a tort committed within the state. ${ }^{3}$ Following in this trend is an even more progressive North Carolina statute, ${ }^{4}$ which, in addition to allowing suits against foreign corporations arising out of isolated local contracts or torts, would also permit suits on a cause of action deriving from mere local business solicitations, by mail or otherwise. ${ }^{5}$ Further, by its broadest section, this statute would expose a foreign corporation to local suit on a claim arising out of the production or distribution of goods with the reasonable expectation that the goods would be consumed in North Carolina. ${ }^{6}$ Although neither statute has

\footnotetext{
${ }^{1}$ The traditional view is that single or isolated transactions are not sufficient bases for jurisdiction. E.g., Rosenberg Bros. v. Curtis Brown Co., 260 U.S. 5 I6 (1922). See generally, BEALE, CONFLICT OF LAWS $\$ 89.4-9$ I.I (1935); I8 Fletcher, CORPoraTIONS $\$ 87$ I3 $_{3}$ (Rev. and perm. ed. 1933). The modern test now emerging is based on reason and limited only by the requirement that the jurisdiction asserted must not be contrary to "fair play and substantial justice." See McBaine, Jurisdiction Over Foreign Corporations: Actions Arising Out of Acts Done Within the Forum, 34 CALIF. L. REv. 33 I (r946).

2MD. CoDe ANn. art. 23, $\$ 88$ (d) (Flack 1951).

a "Every foreign corporation shall be subject to suit in this State by a resident of this State or by a person having a usual place of business in this State on any cause of action arising out of a contract made within the State, whether or not such foreign corporation is doing or has done business in this State." MD. CODE ANn. art. 23, $\S 88$ (d) (Flack 1951).

N.C. GEN. STAT. § 55-145 (1955).

5 "Every foreign corporation shall be subject to suit in this State by a resident of this State or by a person having a usual place of business in this State ... on any cause of action arising as follows: ( $\mathrm{r}$ ) Out of any contract made in this State or to be performed in this State; or (2) Out of any business solicited in this State by mail or otherwise if the corporation has repeatedly so solicited business, whether the orders or offers relating thereto were accepted within or without the State; or ... (4) Out of tortious conduct in this State, whether arising out of repeated activity or siugle acts, and whether arising out of misfeasance or nonfeasance. See note 4 supra.

- "Out of the production, manufacture, or distribution of goods by such corporation with the reasonable expectation that those goods are to be used or consumed in this State
} 
yet been fully tested in the courts, ${ }^{7}$ the recent holding in Compania $D e$ Astral v. Boston Metals Co. ${ }^{8}$ seems favorably disposed toward the Maryland act.

A foreign corporation was sued in Maryland for the breach of a contract executed within the state. ${ }^{9}$ Although the defendant had not qualified to do business locally and had had no previous contacts within the state, jurisdiction in the matter was urged to have been conferred by the liberal terms of the Maryland statute. The Maryland court of appeals, affirming the trial court's assumption of jurisdiction, held that application of the statute was not inconsistent with the requirements of due process. ${ }^{10}$ At the same time, however, the court found that, though the defendant had executed but one contract within the state, the nature and extent of that contract was such as to involve a number of significant local "contacts." 11 It is not unlikely that these contacts were substantial enough to sustain jurisdiction even under well-accepted principles; and the decision, therefore, cannot be taken as an unqualified approval of the Maryland statute. ${ }^{12}$

Courts, in the days of the power-over-the-present-person concept of

and are so used or consumed, regardless of how or where the goods were produced, manufactured, marketed, or sold or whether or not through the medium of independent contractors or dealers." See note 4 supra.

" Since its enactment in 1937 the Maryland statute has been the subject of heated controversy. See generally, Reiblich, Jurisdiction of Maryland Courts Over Foreign Corporations Under the Act of 1937, 3 MD. L. REv. 35 (1938); Legis. Note, $3^{8}$ Colum. L. REv. ro6o (1938); Edgewater Realty Co. v. Tennessee Coal, Iron \& R.R. Co. 49 F. Supp. 807 (D.Md. 1943). In Johns v. Bay State Abrasive Products Co., 89 F. Supp. 654 (D.Md. 1950), the only other case decided under this statute, the action stemmed from a negligent misrepresentation by defendant corporation's salesinan concerning machinery sold to the resident plaintiff. Defendant's activities of regular and continuous solicitation were held sufficient "minimum contacts" to make jurisdiction over it "reasonable." The case presented small challenge to the statute's constitutionality however, since the decision would probably have been the same under a statute with a "doing business" test. See Note, 64 HARv. L. REv. 500 (1951). No cases have yet arisen under the North Carolina statute, which became effective May 20, 1955.

${ }^{8}$ roy A.2d 357 (Md. 1954).

- The contract was entered into after many months of negotiation, for the sale of two vessels in the Baltimore harbor. By the terms of the contract, Maryland law was expressly made controlling. A Baltimore bank held $\$ 85,000$ in escrow for liquidated damages.

${ }^{10}$ Objections based upon denial of due process may concern issues of procedure, which deal with the propriety of service of process; or substance, which are concerned with the power of the state to authorize jurisdiction. This note considers only the latter.

${ }^{11}$ See note 9 supra.

${ }^{12}$ See note 7 supra. 
jurisdiction, ${ }^{13}$ rationalized the amenability of a foreign corporation ${ }^{14}$ to process on the ground that the state, having the power to exclude such a corporation, ${ }^{15}$ could require its submission to the jurisdiction of the state courts as a condition of doing business within its borders. ${ }^{16}$ And even where a foreign corporation conducted business without having qualified to do so, it was deemed to have "impliedly consented" to jurisdiction. ${ }^{17}$ This fiction was vitiated, however, by construction of the

${ }^{13}$ For an excellent exposition of this rationale, see McDonald v. Mabee, 243 U.S. 90 (1916). See also, Mr. Justice Holmes' historical summary in Michigan Trust 'Co. v. Ferry, 228 U.S. 346,353 ( 1912 ). Traditionally, in personam jurisdiction was based upon "allegiance," "domicile," "presence," or "consent." This note discusses only the last two.

${ }^{14}$ Pertinent to the problem of jurisdiction over foreign corporation is the separate development in the law of jurisdiction over non-resident individuals. The early rule, announced in Pennoyer v. Neff, 95 U.S. 714 ( 1877 ), denied in personam jurisdiction over non-resident individuals; non-resident motorist statutes have cut into this rule. Kane v. New Jersey, 242 U.S. I6o (I916); Hess v. Pawloski, 274 U.S. 352 (I927). This variation was later extended to include cases involving contracts for the sale of securities within a state. Henry L. Doherty \& Co. v. Goodman, 294 U.S. 623 (1935). Since both types of cases involve activities which vitally concern the state, the holdings were based upon the principle of the state's overriding right of regulation. See GoodRICH, CONFLICT OF LAWS I 88 ( 3 d ed. 1949). Any further extension of jurisdiction was believed to be unconstitutional. Thus, Flexner ซ. Farson, 248 U.S. 289 ( I9 18), reasoned that, since jurisdiction over foreign corporations was derived from the state's right to exclude them, a similar rule could not apply to non-resident individuals. In recent years, however, the Flexner doctrine has begun to give way to tests of "reasonableness"; and the coalescence of the jurisdictional rules applicable to the foreign corporation and the non-resident individual appears inevitable, if not already accomplished by the case of International Shoe v. Washington, 326 U.S. 3 10 (1945). See Note, 3 DurE B.J. 78 (1953); Note, Growth of the International Shoe Doctrine, I6 U. CHI. L. REv. 523, 534 (1949). As a result, a number of states have enacted statutes granting jurisdiction over non-resident individuals. Most such statutes invoke the "doing business" test. Cf. Ill. Stat. ANN. ro4.017 (Jones 1955).

${ }^{15}$ See, e.g., Paul v. Virginia, 75 U.S. (8 Wall.) (1868), in which the court observed that the state had the right to exclude a foreign corporation from transacting business within its borders, on the strength of the dictum in Bank of Augusta v. Earle, 38 U.S. ( 13 Pet.) 277 ( 1839 ), to the effect that a corporation was not a "citizen" under Article IV of the Constitution, and thus not entitled to the privileges and immunities guaranteed therein.

${ }^{10}$ Statutes in every state require a foreign corporation, which intends to do business within the state, to qualify by appointing an agent for service of process. This note is concerned only with the situation where there has been no such qualification.

${ }^{17}$ It was first thought impossible to gain jurisdiction over the foreign corporation other than by an in rem proceeding, except when it had consented. M'Queen v. Middletown Manufacturing Co., I6 Johns. 5 (N.Y. I8I9). Later the theory of "implied consent" was formulated to uphold statutes authorizing in personam service. Lafayette Ins. Co. v. French, 59 U.S. (I 8 How.) 340 (1855). At first, "consent" was implied from the acts constituting doing business in the state; but when the corporation clearly 
commerce clause ${ }^{18}$ which denied a state the right completely to exclude corporations doing interstate business. ${ }^{19}$

A more durable approach to the problem was the application of the theory that presence is a prerequisite to jurisdiction, and that a corporation $^{20}$ is "present" where it is doing business. ${ }^{21}$ Here, the chief difficulty

manifested no intention to consent, it was implied in law on the basis of the right to exclude. See, e.g., Smolik v. Philadelphia \& Reading Coal Co. 222 Fed. 148 (S.D.N.Y. I9I5).

${ }_{18}$ U.S. Const. art. I, $\$ 8$, cl. I.

${ }^{10}$ In 1910, judicial construction of the commerce clause denied a state the right to exclude from state courts foreign corporations which had not complied with state laws requiring appointment of agents. International Text Book v. Pigg, 217 U.S. 91 (1910); Sioux Remedy Co. v. Cope, 235 U.S. I97 (1914). Nor could the state expel or excessively fine a corporation exclusively engaged in interstate commerce for non-compliance. Crutcher v. Kentucky, r4 I.S. 47 (1891). But as to intrastate commerce carried on by a corporation also engaged in interstate commerce, cf. Osborne v. Florida, I64 U.S. 650 (1896); Western Union v. Kansas, 2 r6 U.S. I (1910); Interstate Amusement Co. v. Albert, 239 U.S. 560 (1916); Davis v. Farmer's Co-op., 262 U.S. 312 (1923). Although a state may not exclude an interstate corporation, it may validly impose reasonable conditions on admission. Amenability to jurisdiction has been held to be a reasonable condition. Tauza v. Susquehanna Coal Co., 220 N.Y. 259, 115 N.E. 915 (1917). See generally Farrier, Jurisdiction over Foreign Corporations, 17 MiNN. L. REv. 270 (1933); McGowan, Litigation as a Burden on Interstate Commerct, 33 ILL. L. REv. 875 (1939); 46 Colum. L. REv. 643 (1946). For discussion of the commerce clause objections to the Maryland statute (which were not raised in Astral v. Bostont Metals), see Reiblich, Jurisdiction of Maryland Courts Over Foreign Corporations, 3 MD. L. REv. 35 ( 1937 ).

${ }^{20}$ The rule as to partnerships, and other unincorporated business associations, is that if the partnership is subject to suit as a separate entity in the jurisdiction-seeking state, or in the state of residence of the partnership, the "doing business" test of foreign corporations is applicable to it by the employment of the comity clause. Sec, e.g., Hemphill v. Orloff, 277 U.S. 537 (1927); Esteve Bros. v. Harrell, 272 Fed. 382 (5th Cir, 1921); Sugg v. Thornton, 132 U.S. 524 (1889); REstatement, Conflicts $\$ 86$ (1934); Beale, Conflict of Laws, \$ 86.1 (1935); Magruder and Foster, Jurisdiction over Partnerships, 37 HARv. L. REv. 793 (1924). If the members of the partnership are subject to suit only as individuals, however, a different rule applies. See, e.g., Western Mut. Fire Ins. Co. v. Lamson Bros., 43 F. Supp. 1007 (S.D. Iowa 194I). The International shoe decision would seem to require only that the partnership have "certain minimum contacts" within the state to subject it as an entity, or the partners as individuals, to jurisdiction. See, e.g., ARK. STATs. ANN. 27-340 (I947) ; Gillioz v. Kincannon, 213 Ark. 1014, 214 S.W.2d 212 (1948); Note, 3 Ark. L. Rev. 22 (1947).

${ }^{21}$ An early recognition of the "presence" theory was forestalled by Mr. Justice Taney's geographical approach in Bank of Augusta \%. Earle, 38 U.S. (13 Pet.) 277 , $282(1839)$ : "[The corporation] exists only in contemplation of law . . and where that law ceases to operate . . the corporation can have no existence." After being foreshadowed in the state [Moulin v. Trenton Mut. Life Ins. Co., 25 N.J.L. 57 (1855)] and English courts [Newby v. Von Oppen, [r872] 7 Q.B. 293] the theory was adopted in Barrow Steampship Co. v. Kane, 170 U.S. 100 (1897). The "presence" doctrine 
lay in the determination of what transactions were embraced by the rather inexact concept of "doing business."22 Eventually, however, the term came to be regarded as but a conclusion of fact reached after applying a standard of reasonableness to the claim of jurisdiction asserted. ${ }^{23}$ The landmark case in this development was International Shoe Co. v. Washington, ${ }^{24}$ in which the Supreme Court held that jurisdiction is constitutionally asserted so long as such assertion does not violate "traditional concepts of fair play and substantial justice.”25 To satisfy this standard, "certain minimum contacts"26 are required, the emphasis being on the nature rather than the quantity of the contacts. ${ }^{27}$

Considered in the light of this progression, these two new statutes appear, not as sweeping innovations, but rather as logical steps in a gradual development. Since this development has reached the point where jurisdiction over foreign corporations requires only certain minimum activity within the state, the statutes can be harmonized with that

gradually replaced the "consent" theory; and, after Philadelphia \& Reading Ry. v. McKibbin, 243 U.S. 264 (1916), it became the entrenched rule. For historical discussion, see Henderson, The Position of Foreign Corporations in American Const]TUTIONAL LAW, c. 5 (1918).

${ }^{23}$ In interpreting the term "doing business," certain conventions have developed. Isolated transactions are not enough. Hunter v. Mutual Life Ins. Co. 218 U.S. 573 (1910). The transactions must be continuous or prospectively continuous. Hutchinson v. Chase \& Gilbert, 45 F.2d I 39 (2d Cir. 1930). Mere solicitation is not "doing business." Green v. Chicago B.\&Q. Ry., 205 U.S. 530 (1907). But solicitation plus any extra activity, however, is sufficient. International Harvester Co. v. Kentucky, 234 U.S. 579 (1914). Advertising is not enough. Harrell v. Peters Cartridge Co., 36 Okla. 684,129 Pac. 872 (1913).

${ }^{23} \mathrm{~A}$ clear articulation of this approach is voiced by Judge Hand, in commenting on the International Shoe doctrine: "The Court . . . [gave]a new explanation to corporate "presence," for it held that ... the court must balance the conflicting interests involved: i.e., whether the gain to the plaintiff in retaining the action at home outweighs the burden imposed upon the defendant corporation. ..." Kilpatrick v. Texas \& P. Ry. Co., 166 F.2d 788, 7.90 (2d Cir. 1948).

${ }_{24}{ }_{326}$ U.S. 3 I0 (1945). Mr. Chief Justice Stone delivered the opinion for a unanimous Court.

${ }^{25} I d$., at $3 \times 6$.

${ }^{20}$ Naturally, there is difficulty in determining what constitutes "minimum contacts." In one case, a single act of negligence in repairing a roof was held sufficient. Smyth v. Twin State Improvement Corp., I 16 Vt. 569 , 80 A.2d 664 (r9.5I), note 50 MICH. L. REv. 763 (1951); 27 Notre DAME LAW. II7 (1951); 26 N.Y.U.L.Q. REV. 713 (I95I); I00 U. PA. L. REv. 598 (1952). In Travelers Health Assn. v. Virginia, 339 U.S. 643 (1950), the sending of insurance contracts by mail was deemed to be sufficient "minimum contacts," but this holding loses some force from the fact that the decision was five to four, and the case involved a state regulatory statute. The same result was reached, however, in Storey v. United Ins. Co., 64 F. Supp. 869 (E.D.S.C. 1946).

${ }^{27} I d$., at $90 \mathrm{I}$. 
requirement if it is recognized that their only novelty is to redefine "minimum contacts"28 as activity which is of such a nature that its ultimate effect is injury to a person within the state.

This semantic exercise only demonstrates that the current "minimum contacts" test can logically be expanded to accommodate the broad provisions of both the North Carolina and the Maryland statutes. Whether such an accommodation is reasonable, however, may be quite another question. ${ }^{29}$ The flexibility of the "minimum contacts" test should not obscure the fact that out-of-state parties must, in fairness, be protected against unreasonable inconveniences in defending suits involving inconsequential transactions. On the other hand, however, if the seemingly isolated transactions of a corporation are regarded not as sporadic attempts to do business within a state, but rather as an integral part of the corporation's over-all scheme of activity, much of the unfairness is dissipated. Since the profits of interstate business can be substantial, it does not seem unreasonable to impose on a corporation the expense of defending claims arising in the deliberate pursuit of these profits.

\section{Gerald R. Grbbons}

\footnotetext{
${ }^{28}$ See generally, McBaine, Jurisdiction Over Foreign Corporations, 34 CALIF. L. REV. 33 I (1946). One of the better arguments for extending jurisdiction is the difficulty in the administration of the "minimum contacts" test. There would certainly be less confusion if the line representing "reasonableness" were drawn at "any cause of action arising within the state," rather than at "minimum contacts." Difficulty conceded, however, justice rather than ease of administration is the end sought, and the cutting of the "gordian knot" in such a manner seems unjustified.

${ }^{20} \mathrm{Mr}$. Justice Black takes the position that jurisdiction is a state concern which should be determined by the states themselves, free from due process review. International Shoe v. Washington, 326 U.S. 3 Io (1945) (concurring opinion); Travelers Health Assoc. v. Virginia, 339 U.S. 643 (1950).
} 